\title{
Tingkat PHK Dan Faktor-Faktor Penyebab PHK Pada Industri Otomotif Selama Masa Pandemi Covid-19
}

\section{Denisa Dominggus ${ }^{1}$, Johnson Dongoran ${ }^{2}$}

1,2 Universitas Kristen Satya Wacana Salatiga, Indonesia

\section{ART I CLE IN F O}

Article history:

Received August 15, 2021

Revised Auguts 19, 2021

Accepted September 30, 2021

Available online November 25, 2021

Kata Kunci:

Faktor Penyebab PHK, Industri Otomotif

Keywords:

Factors That Cause Layoffs,

Automotive Industri

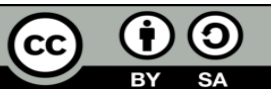

This is an open access article under the $C C$ BY-SA license.

Copyright (C) 2021 by Author. Published by Universitas Pendidikan Ganesha.

\begin{abstract}
A B S T R A K
Kebijakan pelaksanaan pembatasan sosial berskala besar (PSBB) telah memberikan dampak pada meningkatnya jumlah karyawan yang di PHK. Tujuan penelitian ini adalah untuk mengetahui tingkat PHK dan mengidentifikasi faktorfaktor yang penyebab PHK pada industri otomotif selama pandemi Covid-19. Penelitian ini tergolong kedalam jenis penelitian penelitian kualitatif, dengan populasi yakni seluruh pelaku industri otomotif. Penarikan sampel dalam penelitian ini dilakukan dengan menggunakan Teknik purposive sampling, dengan jumlah sampel akhir yakni 7 orang Manajer/Pimpinan dari industri otomotif. Pengumpulan data dalam penelitian dilakukan dengan menggunakan metode observasi, wawancara, dan qiusioner. Dengan instrument penelitian berupa angket faktor penyebab PHK pada industri otomotif. Data hasil penelitian kemudian dianalisis dengan menggunakan Teknik analisis deskriptif kualitatif, yakni dengan mendeskripsikan data hasil penelitian yang kemudian disesuaikan dengan data hasil penelitian terdahulu. Hasil penelitian menunjukkan bahwa tingkat PHK pada industri otomoti Kota Palopo meningkat menjadi $20 \%$ hingga $30 \%$. Sedangkan faktor-faktor penyebab PHK yaitu menurunnya permintaan yang drastis seiring melemahnya daya beli masyarakat, adanya karyawan yang tidak mencapai target penjualan, serta karyawan yang memasuki usia pensiun dan karyawan kontrak yang masa kontraknya telah habis.
\end{abstract}

\section{A BS TR A C T}

The policy of implementing large-scale social restrictions (PSBB) has had an impact on the increasing number of employees being laid off. The purpose of this study was to determine the rate of layoffs and identify the factors that caused layoffs in the automotive industri during the Covid-19 pandemic. This research belongs to the type of qualitative research research, with a population of all automotive industri players. Sampling in this study was carried out using purposive sampling technique, with the final sample being 7 managers/leaders from the automotive industri. Data collection in the study was carried out using the methods of observation, interviews, and questionnaires. With a research instrument in the form of a questionnaire on the factors causing layoffs in the automotive industri. The research data were then analyzed using qualitative descriptive analysis techniques, namely by describing the research data which were then adjusted to the data from previous research. The results showed that the rate of layoffs in the automotive industri of Palopo City increased to $20 \%$ to 30\%. Meanwhile, the factors causing layoffs were the drastic decline in demand due to the weakening of people's purchasing power, the presence of employees who did not reach their sales targets, as well as employees entering retirement age and contract employees whose contract period had expired.

\section{PENDAHULUAN}

Industri otomotif merupakan salah satu industri yang memiliki peran penting dalam perkembangan perekonomian di Indonesia (Pikahulan, 2018; Winardi et al., 2019). Industri otomotif telah menjadi pilar penting dalam perkembangan sektor manufaktur negara (Ramadhan et al., 2019). Adanya perkembangan rantai bisnis mulai dari manufaktur komponen, manufaktur kendaraan itu sendiri, jaringan distribusi dan layanan purna jualnya, baik bengkel resmi maupun umum, termasuk jaringan distribusi suku cadang di seluruh Indonesia disebabkan karena sebagian besar penduduk Indonesia memilih untuk memiliki kendaraan pribadi masing-masing (Prabowo \& Sutanto, 2019; Yanti, 2020). Hal ini juga membuat banyak investor tertarik untuk menanamkan modal mereka pada perusahaan-perusahaan otomotif di Indonesia selain itu terdapat banyak perusahaan mobil yang terkenal di dunia membuka (kembali) pabrikpabrik manufaktur atau meningkatkan kapasitas produksinya di Indonesia dengan ekonomi terbesar di Asia Tenggara ini (Mujiyono, 2021; Rachmawati \& Rismayani, 2019). Hal ini kemudian menjadikan Indonesia sebagai negara pemilik industri manufaktur terbesar kedua setelah negara Thailand (Nurapiah, 2019; Sumilat et al., 2021). 
Hanya saja dalam beberapa tahun terakhir, perkembangan industri otomotif di Indonesia mengalami penurunan (Biki et al., 2021; Sutantri et al., 2021). Hal ini disebabakan karena adanya penyebaran virus pandemic covid-19 yang melanda seluruh wilayah Indonesia. Virus covid-19 merupakan virus yang menyerang sistem pernapasan manusia yang mengakibatkan penderitanya mengalami sesak napas. Virus covid-19 bersifat menular dan dapat menyebabkan kematian jika penderitanya terlambat mendapatkan penanganan. Untuk mengurangi jumlah korban jiwa akibat terpapar virus covid-19 pemerintah mengeluarkan kebijakan pelaksanaan pembatasan sosial berskala besar (PSBB) yang mengakibatkan tutupnya sebagian perusahaan, termausk perusahaan otomotif karena mengalami kerugian yang berdampak pada ketidakmampuannya untuk memberi upah karyawannya (R. K. Putri et al., 2020; Widiastuti \& Silfiana, 2021). Hal ini sejalan dengan hasil observasi yang menunjukkan hasil bahwa pandemi covid-19 yang berlangsung sejak awal tahun ini juga menjadi pukulan berat bagi industri otomotif di wilayah Indonesia. Gabungan Industri Kendaraan Bermotor Indonesia (Gaikindo) mengatakan bahwa pandemi Covid-19 dapat menghambat laju industri otomotif di Indonesia secara berkesinambungan. Selain pengaruh dari tekanan global khususnya China selaku salah satu pengekspor bahan baku utama di sektor otomotif, pemberlakuan Pembatasan Sosial Berskala Besar (PSBB) di sejumlah wilayah Indonesia juga terus dilakukan perpanjangan.

Upaya yang dilakukan para pelaku industri otomotif untuk mengurangi kerugian pasca pandemi yakni dengan melakukan pemutusan hubungan kerja (PHK) pada para karyawan yang bekerja di perusahaan tersebut (Juaningsih, 2020). Pemutusan hubungan kerja merupakan hilangnya pekerjaan yang berarti berkurangnya sebagian gaji atau upah yang menjadi sumber penghasilan karyawan (Muslim, 2020; Yitawati et al., 2021). Adanya PHK besar-besaran pada masa pandemic covid-19 menjadi awal hilangnya mata pencaharian bagi pekerja yang juga menyebabkan kehilangan pekerjaan dan penghasilan (Salasiah et al., 2020). Data dari Kementerian Ketenagakerjaan dan BPJS Ketenagakerjaan, menunjukkan bahwa pekerja yang terdampak langsung akibat Covid-19 terdapat 2,8 juta pekerja (Dewi et al., 2020). Pekerja formal yang dirumahkan terdiri dari 1,7 juta jiwa dan 749,4 ribu jiwa di PHK (Agustiana, 2020). Selanjutnya, pekerja informal yang usahanya terganggu terdapat 282 pekerja (Siregar \& Oktaviana, 2020). Disisi lain Badan Perlindungan Pekerja Migran Indonesia (BP2MI) mencatat terdapat 100.094 Pekerja Migran Indonesia (PMI) yang berasal dari 83 negara pulang ke Indonesia dalam periode tiga bulan terakhir. CORE Indonesia memprediksikan tingkat pengangguran terbuka pada kuartal II 2020 hingga 8,2\% dengan skenario ringan, skenario sedang sebesar 9,79\% dan untuk skenario besar sebesar 11,47\%. Dana Moneter Indonesia (IMF) untuk angka pengangguran di Indonesia pada tahun 2019 yang hanya sebesar 5,3\%, pada 2020 diproyeksikan naik sebesar 7,5\% (Agustiana, 2020). Berdasarkan data dari Badan Pusat Statistik (BPS) tingkat pengangguran terbuka di Indonesia pada tahun 2020 bulan Februari tercatat sebesar 05,01\% (Juliannisa et al., 2021; Putri et al., 2021).

Besarnya tingkat PHK di masa pandemi covid-19 cenderung disebabkan karena permintaan terhadap barang dan bahan baku industri anjlok tajam seiring melemahnya daya beli masyarakat (Muslim, 2020). Selain itu ketersediaan bahan baku di industri yang mulai menipis dan meningkatkatnya harga bahan baku juga menjadi salah satu faktor merosotnya jumlah pendapatan di dunia industry (Juaningsih, 2020). Beberapa penelitian yang telah dilakukan mengungkapkan bahwa potensi terjadinya pengurangan karyawan yang berakibat PHK dikarenakan bahan baku berkurang yang menyebabkan produksi menurun (Hernawati et al., 2021). Hasil penelitian lainnya juga mengungkapkan bahwa pemutusan hubungan kerja pada masa pandemi covid-19 disebabkan karena menurunnya hasil penjualan produk sehingga Sejumlah produsen menghentikan proses produksi (Indayani \& Hartono, 2020). Hasil penelitian selanjutnya juga mengungkapkan tentang wabah tentang wabah Covid-19 terhadap tingkat pengangguran terbuka pada sektor terdampak di Indonesia, yang mencakup Indonesia sebagai negara, dengan hasil penelitian faktor pribadi memiliki pengaruh yang signifikan terhadap pemutusan hubungan kerja karyawan (Agustiana, 2020). Berdasarkan hasil tersebut dapat dikatakan bahwa pemutusan hubungan kerja karyawan pada masa pandemic covid-19 cenderung disebabkan karna menurunnya proses produksi dan jumlah konsumen. Hanya saja pada penelitian sebelumnya belum terdapat kajian mengenai faktor-faktor yang menjadi penyebab adanya pemutusan hubungan kerja pada industri otomotif di masa pandemi. Sehingga penelitian ini difokuskan pada kajian tersebut dengan tujuan untuk mengetahui tingkat PHK pada industri otomotif selama masa pandemi Covid-19 dan untuk mengidentifikasi faktor-faktor penyebab PHK pada industri otomotif selama masa pandemi Covid-19.

\section{METODE}

Metode penelitian yang digunakan adalah jenis penelitian kualitatif yaitu suatu prosedur penelitian yang menggunakan data deskriptif berupa kata-kata tertulis atau lisan untuk memahami atau menafsirkan fenomena yang sedang dialami oleh orang-orang yang diamati. Penelitian ini dilaksanakan di 
beberapa industri otomotif Kota Palopo, dengan populasi penelitian yakni seluruh pelaku industri otomotif di kota palopo. Penarikan sampel dalam penelitian ini dilakukan dengan menggunakan Teknik purposive sampling. Adapun sampel dalam penelitian ini yakni 7 orang Manajer/Pimpinan dari industri otomotif. Pengumpulan data dalam penelitian dilakukan dengan menggunakan metode observasi, wawancara, dan qiusioner. Dengan instrument penelitian berupa angket faktor penyebab PHK pada industri otomotif. Data hasil penelitian kemudian dianalisis dengan menggunakan Teknik analisis deskriptif kualitatif, yakni dengan mendeskripsikan data hasil penelitian yang kemudian disesuaikan dengan data hasil penelitian terdahulu.

\section{HASIL DAN PEMBAHASAN}

\section{Hasil}

Melalui proses observasi, wawancara, dan penyebaran angket kepada sampel penelitian didapatkan dua hasil dalam penelitian ini. Hasil pertama berkaitan dengan Tingkat PHK pada industri otomotif selama masa pandemi Covid-19. Berdasarkan hasil penelitian terkait tingkat PHK menunjukkan sebanyak enam responden mengatakan bahwa pendemi Covid-19 berpengaruh terhadap tingkat PHK karyawan pada industri otomotif, karena kondisi pandemi saat ini telah menyebabkan perusahaan mengalami penurunan penjualan, sehingga pendapatan bagi perusahaan menurun. Sementara satu responden mengatakan tidak berpengaruh banyak, dikarenakan perusahaan tetap menjalankan sistem WFH/WFO. Selanjutnya pada pertanyaan kedua mengenai seberapa besar tingkat PHK sebagai akibat adanya pandemi Covid-19, menunjukkan hasil bahwa sebanyak empat responden mengatakan 30\% berpengaruh, dan tiga responden mengatakan $20 \%$ berpengaruh. Berdasarkan hasil wawancara juga didapatkan informasi bahwa pada kondisi pandemi saat ini perusahaan terdorong untuk melakukan berbagai perubahan terhadap kegiatan yang sebelumnya tidak dilakukan, seperti pengurangan jam kerja karyawan lebih dibatasi dan menghimbau karyawan untuk melakukan physical distancing di tempat kerja agar memutus mata rantai penyebaran virus Covid-19.

Hasil penelitian kedua, berkaitan dengan faktor-faktor penyebab PHK pada industri otomotif selama masa pandemi Covid-19. Berdasarkan hasil penelitian terkait menurunnya permintaan terhadap otomotif menunjukkan sebanyak enam dari tujuh responden mengatakan bahwa menurunnya permintaan terhadap otomotif menjadi penyebab terjadinya PHK terhadap karyawan. Sementara satu responden mengatakan bahwa kurangnya permintaan terhadap otomotif selama masa pandemi bukan suatu alasan besar sehingga perusahaan melakukan PHK besar-besaran. Jadi pernyataan tersebut menunjukkan bahwa perusahaan otomotif tetap melakukan cara terbaik demi menyejahterakan karyawan dan perusahaan. Selain itu hasil penelitian juga menunjukkan bahwa sebanyak enam dari tujuh responden mengatakan dampak pandemi mengakibatkan perusahaan otomotif mengalami penurunan permintaan yang drastis, karena kondisi saat ini membuat daya beli masyarakat pada kendaraan menjadi berkurang. Hal tersebut menyebabkan pendapatan bagi perusahaan menurun, sehingga perusahaan tidak sanggup untuk meneruskan produktivitas usaha hingga harus melakukan pemutusan hubungan kerja (PHK). Sementara satu responden mengatakan bahwa PHK karyawan dalam perusahaan tidak semata-mata hanya karena melemahnya daya beli masyarakat, tetapi banyak faktor-faktor yang bisa terjadi di lingkungan perusahaan yang dapat menyebabkan karyawan terkena PHK. Jadi pernyataan tersebut menunjukkan bahwa pandemi Covid-19 tidak dapat dijadikan sebuah alasan bagi perusahaan untuk melakukan PHK.

Berdasarkan hasil penelitian terkait ketersediaan otomotif dari negara-negara eksportir menunjukkan sebanyak tiga responden mengatakan bahwa akibat pembatasan yang masih berlaku di sejumlah negara membuat bahan baku industri otomotif berkurang, hal tersebut menyebabkan produksi menurun, sehingga berpotensi dilakukan pengurangan karyawan dengan cara PHK. Satu responden mengatakan bahwa perusahaan otomotif memesan produk langsung dari agen tunggal pemegang merek (ATPM) di Jakarta. Dengan diterapkannya Pembatasan Sosial Berskala Besar (PSBB) membuat waktu pengiriman kepada industri otomotif yang menjadi mitra bisnisnya terhambat. Hal tersebut membuat stok unit di perusahaan menipis, sehingga pendapatan perusahaan pun menurun. Sementara tiga responden mengatakan bahwa ketersediaan otomotif dari negara eksportir tidak memengaruhi PHK pada karyawan, dikarenakan perusahaan sudah memproduksi unit di negara masing-masing. Adapun faktor lain yang menyebabkan perusahaan melakukan PHK yaitu ketika karyawan melakukan pelanggaran ketentuan yang diatur dalam perjanjian kerja, seperti tidak melaksanakan tugas dan kewajibannya dalam mencapai target penjualan. Satu responden mengatakan bahwa PHK juga dapat terjadi ketika karyawan memasuki usia pensiun. Sementara satu responden mengatakan bahwa perusahaan juga melakukan PHK kepada karyawan kontrak yang mana masa kontraknya telah habis, jadi tidak diperpanjang lagi. 


\section{Pembahasan}

Berdasarkan hasil penelitian didapatkan dua temuan dalam penelitian ini. Hasil penelitian pertama menunjukkan bahwa pandemi Covid-19 sangat berpengaruh terhadap tingkat PHK karyawan yang menyebabkan tingkat PHK pada industri otomotif selama masa pandemi meningkat menjadi $20 \%$ hingga $30 \%$. Hal tersebut dikarenakan kondisi pandemi saat ini membawa dampak buruk bagi perusahaan yang menyebabkan target penjualan pada perusahaan otomotif menjadi tidak sesuai dengan perencanaan (Sutantri et al., 2021). Perusahaan otomotif mengalami penurunan permintaan yang drastis seiring melemahnya daya beli masyarakat yang membuat pendapatan bagi perusahaan ikut menurun, sehingga perusahaan melakukan PHK (Sari, 2020). Pemecatan hubungan kerja di masa pandemic covid-19 tidak hanya dilakukan oleh pengusaha industri otomotif melainkan juga dilakukan oleh banyak industri besar lainnya (Frivanty \& Ramadhani, 2021; Nazifah \& Mahila, 2021). Upaya lain yang dilakukan pelaku industri untuk mengurangi kerugian akibat pandemi yakni dengan mengurangi jam kerja karyawan (Wijaya \& Subekti, 2021). Selain dilakukan untuk mengatasi kerugian pengurangan jam kerja karyawan juga dilakukan untuk mengurangi adanya kerumunan di tempat kerja dan mematuhi arahan pemerintah untuk melaksanakan social distancing (Maghfuroh et al., 2021). Adanya pemutusan hubungan kerja karyawan dan pengurangan jam kerja disebabkan oleh beberapa faktor. Faktor pertama yakni adanya penurunan daya beli masyarakat. Penurunan daya beli masyarakat di masa pandemi covid-19 cenderung disebabkan karna berkurangnya jumlah penghasilan masyarakat tiap bulannya (Rochma \& Anshori, 2021; Taufik \& Armansyah, 2021). Masyrakat umumnya hanya akan membeli kebutuhan pokok dan mengesampingkan kebutuhan-kebutuhan lainnya, termasuk kebutuhan akan kendaraan (Nawara et al., 2021; Prayogo \& Sukim, 2021). Penurunan daya beli masyarakat juga berdampak pada penghentian proses produksi, sehingga tidak sedikit perusahaan industri yang memilih untuk tutup bahkan mengalami kebangkrutan di masa pandemi covid-19 (Setianingsih \& Wijaya, 2021).

Faktor kedua yang menjadi penyebab perusahaan melakukan PHK yakni, karyawan tidak mampu memenuhi target penjualan. Target penjualan merupakan capaian penjualan yang harus dipenuhi karyawan dalam rentang waktu tertentu (Kusumah, 2020). Tidak tercapainya target penjualan di masa pandemi disebabkan karena kesalahan yang muncul dari perusahaan, yaitu faktor internal dan eksternal, faktor internal antara lain kualitas pelayanan, sedangkan faktor eksternal antara lain perubahan selera konsumen dan kebijakan dari pemerintah (Hartanti et al., 2021). Peningkatan target penjualan dapat dilakukan dengan meningkatkan kualitas produk serta melakukan prosmosi diberbagai media sosial (Margahana, 2020). Faktor ketiga yang menyebabkan adanya PHK yakni usia karyawan yang sudah memasuki usia pensiun serta masa kontraknya telah habis. Perusahaan besar tentunya akan lebih membutuhkan karyawan dengan usia muda yang memiliki keahlian di bidang pemasaran secara digital.

Adanya pemutusan hubungan kerja karyawan di masa pandemi seperti saat ini tentunya berdampak pada peningkatan jumlah pengangguran di masyarakat (Achiel et al., 2020). Sejalan dengan meningkatnya angka pengangguran anggka kemiskinan juga akan semakin meningkat (Silaban et al., 2021). Hal ini menunjukkan bahwa selain memberikan dampak besar bagi aspek kesahatan, pandemi covid-19 juga memberikan pengaruh yang sangat besar bagi perekonomian masyarakat. Masyarakat semakin kesulitan untuk memenuhi kebutuhan hidupanya. Sehingga untuk mengatasi hal tersebut masyrakat perlu mengembangkan berbagai keterampilan guna dapat memenuhi kebutuhan sehari-hari.

Pada bidang industri otomotif adanya pendemi covid-19 telah memberikan dampak pada penurunan jumlah penghasilan dan produksi (Andayani et al., 2021). Hal ini tidak hanya terjadi di Indonesia melainkan juga terjadi di negara maju seperti cina dan jepang. Hasil yang diperoleh pada penelitian ini sejalan dengan hasil penelitian terdahulu yang juga mengungkapkan bahwa potensi terjadinya pengurangan karyawan yang berakibat PHK dikarenakan bahan baku berkurang yang menyebabkan produksi menurun (Hernawati et al., 2021). Hasil penelitian lainnya juga mengungkapkan bahwa pemutusan hubungan kerja pada masa pandemi covid-19 disebabkan karena menurunnya hasil penjualan produk sehingga Sejumlah produsen menghentikan proses produksi (Indayani \& Hartono, 2020). Hasil penelitian selanjutnya juga mengungkapkan tentang wabah tentang wabah Covid-19 terhadap tingkat pengangguran terbuka pada sektor terdampak di Indonesia, yang mencakup Indonesia sebagai negara, dengan hasil penelitian faktor pribadi memiliki pengaruh yang signifikan terhadap pemutusan hubungan kerja karyawan (Agustiana, 2020). Berdasarkan hasil penelitian yang didukung oleh hasil penelitian terdahulu dapat diketahui bahwa faktor utama yang menjadi penyebab adanya PHK yakni menurunnya penjualan produkdi masa pandemic covid-19.

\section{SIMPULAN}

Berdasarkan hasil penelitian dapat disimpulkan bahwa selama masa pandemi tingkat PHK pada industri otomotif meningkat secara drastis. Peningkatan jumlah karya yang di PHK disebabkan karena daya 
beli konsumen menurun, tidak tercapainya target penjualan oleh karyawan, adanya karyawan yang sudah lanjut usia serta telah habisnya masa kontrak karyawan yang bersankutan.

\section{DAFTAR PUSTAKA}

Achiel, Y., Soffy, B., Eka, A. A., \& Kumaya, J. R. (2020). Dampak Pandemi Covid-19 Bagi Pekerja "Phk, Pemotongan Gaji, Dan Motivasi Kerja." Jurnal Psikowipa, 1(2). https://doi.org/10.38156/psikowipa.v1i2.34.

Agustiana, L. E. (2020). Pengaruh Wabah Covid-19 Terhadap Tingkat Pengangguran Terbuka Pada Sektor Terdampak Di Indonesia. Jurnal Ilmu Manajemen Terapan, 1(6), 546-556. https://doi.org/10.31933/JIMT.

Andayani, I., Roesminingsih, M. V., \& Yulianingsih, W. (2021). Strategi Pemberdayaan Masyarakat Pelaku UMKM Di Masa Pandemi Covid-19. Jurnal Pendidikan Nonformal, 16(1), 12. https://doi.org/10.17977/um041v16i1p12-20.

Biki, S. B., Mendo, A. Y., \& Hilala, E. (2021). Kesuksesan Implementasi Sap Human Resource Information System (Hris) Di Industri Otomotif Sunter Jakarta Utara. Jurnal Ilmu Pengetahuan Sosial, 8(7), 2430-2436. https://doi.org/10.31604/jips.v8i7.2021.2430-2436.

Dewi, M. M., Magdalena, F., Ariska, N. P. D., Setiyawati, N., \& Rumboirusi, W. C. B. (2020). Dampak Pandemi Covid-19 terhadap Tenaga Kerja Formal di Indonesia The Impact of Covid-19 Pandemic on Formal

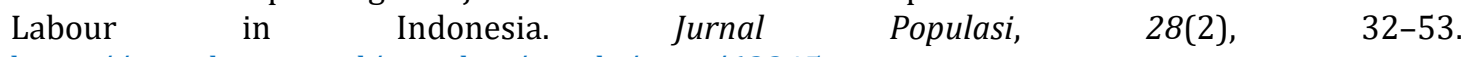
https://jurnal.ugm.ac.id/populasi/article/view/63345.

Frivanty, S., \& Ramadhani, D. A. (2021). Pandemi Covid-19 Sebagai Alasan Perusahaan Untuk Melakukan Pemutusan Hubungan Kerja (PHK) Secara Sepihak. Jurnal Ilmu Hukum Dan Humaniora, 8(2), 262269. https://doi.org/10.31604/justitia.v8i2.262-269.

Hartanti, L. P. S., Yulia, N. A., \& Levina, M. G. (2021). Faktor-Faktor Yang Memengaruhi Penjualan Umkm Sektor Kuliner Di Masa Pandemi Covid-19. Prosiding Webinar Nasional Penelitian Dan Pengabdian Masyarakat Tahun 2021,

$1-2$. https://www.ejournalwiraraja.com/index.php/SNAPP/article/view/1756/1262.

Hernawati, E., Dewi, A. A., Aulia, D., \& Sumunar, K. I. (2021). Pengaruh Covid-19 Terhadap Perekonomian Di Negara Asean. JISIP (Jurnal Ilmu Sosial Dan Pendidikan), 5(3). https://doi.org/10.36312/jisip.v5i3.2228.

Indayani, S., \& Hartono, B. (2020). Analisis pengangguran dan pertumbuhan ekonomi sebagai akibat pandemi covid-19. Jurnal Ekonomi \& Manajemen Universitas Bina Sarana Infoematika, 18(2), 201208. https://doi.org/10.31294/jp.v18i2.8581.

Juaningsih, I. N. (2020). Analisis Kebijakan PHK Bagi Para Pekerja Pada Masa Pandemi Covid-19 di $\begin{array}{lllll}\text { Indonesia. Buletin Hukum Dan } & \text { Keadilan, 4(1), }\end{array}$ https://doi.org/10.15408/adalah.v4i1.15764.

Juliannisa, I. A., Triwahyuningtyas, N., \& Roswita, C. (2021). Dampak Covid Terhadap Perekonomian Secara Makro. Widya Manajemen, 3(1), 1-14. https://doi.org/10.32795/widyamanajemen.v3i1.1098.

Kusumah, J. achmiarti. (2020). Usulan Perumusan Strategi Perusahaan Dengan Analisis Swot Untuk Pencapaian Target Penjualan Cat. Jurnal Ekonomi Manajemen Sistem Informasi, 1(5), 475-489. https://doi.org/10.31933/jemsi.v1i5.155.

Maghfuroh, W., Hariyanto, B., \& Herlambang, T. (2021). Penanganan Problematika Masyarakat Di Masa

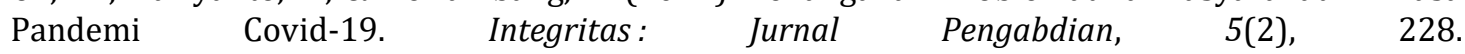
https://doi.org/10.36841/integritas.v5i2.1339.

Margahana, H. (2020). Upaya Peningkatan Penjualan Produk Batu Bata di Desa Kuto Sari Kecamatan Belitang III Kabupaten Ogan Komering Ulu Timur. Dinamisia: Jurnal Pengabdian Kepada Masyarakat, 4(3), 563-569. https://doi.org/10.31849/dinamisia.v4i3.4245.

Mujiyono, S. T. (2021). Pengembangan Sumber Daya Manusia di Industri Otomotif Melalui Institut Otomotif Indonesia. Jurnal Manajemen Strategi Dan Aplikasi Bisnis, 4(2), 13-28. https://doi.org/10.36407/jmsab.v4i2.396.

Muslim, M. (2020). PHK Pada Masa Pandemi Covid-19. Esensi: Jurnal Manajemen Bisnis, 23(3), 357-370. https://ibn.e-journal.id/index.php/ESENSI/article/view/218/194.

Nawara, S., Fikri, A., \& Rikardo, D. (2021). Strategi Bisnis dalam Menghadapi Daya Beli Masyarakat yang Rendah pada Masa Pandemi Covid-19. Jurnal Pendidikan Tambusai, 5(2), 3526-3530. https://doi.org/10.31004/jptam.v5i2.1433.

Nazifah, N., \& Mahila, S. (2021). Perlindungan Hukum Pekerja yang Terkena Pemutusan Hubungan Kerja di Masa Pandemi Covid-19. Jurnal Ilmiah Universitas Batanghari Jambi, 21(3), 1112. https://doi.org/10.33087/jiubj.v21i3.1713. 
Nurapiah. (2019). Pengaruh Profitability , Size Dan Financial Leverage Terhadap Income Smoothing Pada Perusahaan Industri Otomotif Di Bursa Efek Indonesia (BEI ). Jurnal Sinar Manajemen, 6(1), 27-34. https://doi.org/10.31934/jsm.v6i1.548.

Pikahulan, R. M. (2018). Konsep Alih Teknologi Dalam Penanaman Modal Di Indonesia Bidang Industri $\begin{array}{lllll}\text { Otomotif. Jurnal } & \text { Cakrawala } & \text { Hukum, }\end{array}$ https://www.ejournal.up45.ac.id/index.php/cakrawala-hukum/article/view/385.

Prabowo, R., \& Sutanto, A. (2019). Analisis Pengaruh Struktur Modal, dan Likuiditas terhadap Profitabilitas pada Perusahaan Sektor Otomotif di indonesia. Jurnal Samudra Ekonomi Dan Bisnis, 10(1). https://doi.org/10.33059/jseb.v10i1.1120.

Prayogo, D., \& Sukim, S. (2021). Determinan Daya Beli Masyarakat Indonesia Selama Pandemi Covid-19 Tahun 2020. Seminar Nasional Official Statistics, 2021(1), 631-640. https://doi.org/10.34123/semnasoffstat.v2021i1.987.

Putri, A., Azzahra, A., Andiany, D. D., Abdurohman, D., Sinaga, P. P., \& Yuhan, R. J. (2021). Perbandingan Faktor-Faktor Yang Mempengaruhi Tingkat Pengangguran Terbuka Di Indonesia Sebelum Dan Saat Pandemi Covid-19. Jurnal Kajian Ekonomi Dan Pembangunan, 3(2), 25. https://doi.org/10.24036/jkep.v3i2.11592.

Putri, R. K., Sari, R. I., Wahyuningsih, R., \& Meikhati, E. (2020). Efek Pandemi Covid-19: Dampak Lonjakan Angka PHK Terhadap Penurunan Perekonomian di Indonesia. Jurnal Bismak, 1(1), 50-55. https://ojs.udb.ac.id/index.php/BISMAK/article/view/1206/1027.

Rachmawati, V. K., \& Rismayani, R. (2019). Struktur Dan Kinerja Industri Otomotif Indonesia. Jurnal Riset Manajemen Dan Bisnis, 13(2), 113. https://doi.org/10.21460/jrmb.2018.132.309.

Ramadhan, T., Marota, R., \& Mulyaningsih, M. (2019). Pengaruh Perputaran Persediaan, Pertumbuhan Penjualan Dan Likuiditas Terhadap Profitabilitas Pada Perusahaan Sub Sektor Otomotif Dan Komponen Yang Terdaftar Di Bursa Efek Indonesia Periode 2012-2017. Jurnal Online Mahasiswa (JOM) Bidang Akuntansi, 6(2), 1-16. https://jom.unpak.ac.id/index.php/akuntansi/article/view/1538/1255.

Rochma, E. D. nur, \& Anshori, isa. (2021). Ekonomi Buruh Industri Pada Masa Pandemi Covid-19. Jurnal Ilmu Ekonomi \& Sosial, 12(1). https://doi.org/10.35724/jies.v12i1.3373.

Salasiah, S., Diana, D., Fatah, M. A., \& Adriansyah, M. A. (2020). Membangun Kepedulian Pada Sesama di Masa Covid-19. Plakat (Pelayanan Kepada Masyarakat), 160. https://doi.org/10.30872/plakat.v2i2.4973.

Sari, D. I. (2020). Pengaruh Current Rasio Dan Debt To Equity Ratio Terhadap Harga Saham Perusahaan Otomotif. Jurnal Riset Akutansi, 3(1). https://doi.org/10.26533/jad.v3i1.522.

Setianingsih, F. A., \& Wijaya, R. H. (2021). Tinjauan Akuntansi Keperilakuan Terhadap Kebijakan Perusahaan Menghadapi Pandemi Covid-19. Jurnal Penelitian Dan Pendidikan Ekonomi, 18(2). https://doi.org/10.25134/equi.v18i2.4063.

Silaban, E. S., Dwi Arini, D. G., \& Suryani, L. P. (2021). Perlindungan Hukum bagi Pekerja Akibat Pemutusan Hubungan Kerja pada Masa Pandemi Covid-19. Jurnal Preferensi Hukum, 2(3), 543-547. https://doi.org/10.22225/jph.2.3.3998.543-547.

Siregar, A. P., \& Oktaviana, N. (2020). Realokasi Kartu Pra Kerja Dalam Mendukung Intensifikasi Sektor Pertanian. Agrisaintifika: Jurnal Ilmu-Ilmu Pertanian, 4(1), 1. https://doi.org/10.32585/ags.v4i1.843.

Sumilat, A. G., Mangantar, M., \& Maramis, J. B. (2021). Komparasi Kinerja Keuangan Pada Perusahaan Otomotif Di Bei (Studi Pada Perusahaan Dengan Single Segmen Vs Multi Segmen). Jurnal Emba: Jurnal Riset Ekonomi, Manajemen, Bisnis Dan Akuntansi, 9(2). https://doi.org/10.35794/emba.v9i1.32582.

Sutantri, S. C., Moenardy, D. F., \& Fitri, R. J. (2021). Investasi Ekonomi Jepang Di Inggris Dalam Bidang Industri Otomotif Pada Masa Transisi Brexit 2014-2018. Jurnal Bisnis, Ekonomi, Dan Sains, 1(1), 2130. http://journal.widyatama.ac.id/index.php/bes/article/view/648.

Taufik, M., \& Armansyah, A. (2021). Eksistensi Pelaku Usaha Sektor Informal Offline dan Online di Tengah. Publikauma: Jurnal Administrasi Publik Universitas Medan Area, 9(1), 57-66. https://doi.org/10.31289/publika.v9i1.4846.

Widiastuti, A., \& Silfiana, S. (2021). Dampak Pandemi Covid-19 Terhadap Pertumbuhan Ekonomi Di Pulau Jawa. Jurnal Ekonomi-Qu, 11(1), 97. https://doi.org/10.35448/jequ.v11i1.11278.

Wijaya, A. T., \& Subekti, R. (2021). Penyelesaian Perselisihan Pemutusan Hubungan Kerja (PHK) Pada Masa Pandemi Covid-19 Melalui Mediator. Jurnal Pendidikan Kewarganegaraan Undiksha, 09(02), 474485. https://doi.org/10.23887/jpku.v9i2.34150.

Winardi, W., Priyarsono, D. S., Siregar, H., \& Kustanto, H. (2019). Peranan Kawasan Industri dalam Mengatasi Gejala Deindustrialisasi. Jurnal Ekonomi Dan Pembangunan Indonesia, 19(1), 84-95. 
https://doi.org/10.21002/jepi.v19i1.834.

Yanti, N. (2020). Analisi Economic Value Added (Eva) Dan Return on Assets (Roa) Terhadap Nilai Perusahaan. Pareso Jurnal, 2(4), 291-312. http://ejurnalunespadang.ac.id/index.php/PJ/article/view/235.

Yitawati, K., Triharyani, A., \& Purwati, Y. (2021). Perlindungan Hukum Pekerja Terdampak Pemutusan Hubungan Kerja (PHK) Dalam Masa Pandemi Covid 19. Jurnal Yustisia Merdeka, 7(2). https://doi.org/10.33319/yume.v7i2.112. 